\title{
INDIVIDUAL FACTORS FOR NASCENT DIGITAL ENTREPRENEURSHIP- FIRST HYPOTHESES
}

\author{
Jan Vogt ${ }^{1}$ and Marie-E. Godefroid ${ }^{2}$ \\ ${ }^{I}$ FernUniveristät Hagen, Germany \\ ${ }^{2}$ Universität Siegen, Germany
}

\begin{abstract}
Extreme events are a challenge for any economy. That's why the state has an interest in promoting the capacity for innovation that helps to cope with extreme events and their consequences. One part of these innovations that is particularly relevant in the current pandemic is digital startups. Therefore, assessing the starting points for possible interventions to increase the number of digital startups is necessary. To shape policy interventions, this paper provides hypotheses on individual factors that can form the basis for designing these policy interventions. We first identify different factors in the pre-start-up stage influencing the individual to become a nascent entrepreneur cited in general literature and then derive hypotheses promoting nascent digital entrepreneurship. We propose to test these hypotheses in further research, for example, through experimental tests of factor effects. These findings also hold potential for practitioners.
\end{abstract}

\section{KEYWORDS}

Digital Start-Ups, Digital Entrepreneurship, Nascent Entrepreneurs, Literature Review, Individual Factors, Influencing Factors for Digital Entrepreneurs

\section{INTRODUCTION}

Extreme events are an enormous challenge for any economy. Covid-19 is an extreme event altering the business landscape fundamentally, illustrating the need for an overarching digital transformation of companies and start-ups (Soto-Acosta 2020). That's why the state has an interest in promoting the capacity for innovation that helps to cope with extreme events and their consequences. Digital start-ups are especially vital, as they create value for the society at large, but founders are still scarce (Global Entrepreneurship Research Association 2020; Metzger 2020). Even before the crisis, the KfW-Start-Up-Report 2020 revealed that only 70.000 start-ups originated in Germany in 2019. Entrepreneurship figures are substantially lower than, for example, in the US, where 17.4 percent of the adults engage in early-stage entrepreneurial activities, whereas in Germany, only 7.6 percent do (Bosma et al. 2020).

Start-ups create jobs, lead to economic growth (Ahlstrom 2010), and boost innovation, productivity, and competitiveness (Skawińska and Zalewski 2020). Naturally, one should maintain realistic expectations regarding their benefits since especially a small number of high-growth firms create new jobs (Summers 2015). Extreme events change the framework conditions and thus create new entrepreneurial opportunities and change risk perception because the risk of alternative activities changes (Kuckertz et al. 2020). Therefore, it is necessary to assess possible starting points for interventions to increase the number of people engaging in digital entrepreneurship.

In our research approach, we define our scope along two dimensions: life cycle phase and factor type. Firstly, different actions along a start-up's life cycle can increase the number of digital start-ups. There are several life cycle models for start-ups from different perspectives, for example, Overall and Wise (2015) from a financial perspective or Reisdorfer-Leite et al. (2020) with a focus on life cycle management. But all of these models have a start or pre-start phase in common, which is assessed in more detail in a model by Van Gelderen et al. (2006). The researchers name four phases in their model: Entrepreneurial opportunity recognition, business concept development, resource assembly or start-up creation, and product offering. In each phase, different factors are essential for aspiring, nascent, and fledgling entrepreneurs (Rotefoss and 
Kolvereid 2005). Secondly, focusing on different success factors in the pre-start-up phase that influence founders or nascent entrepreneurs can increase the number of (digital) entrepreneurs. Van Gelderen et al. (2006) define a person who is undertaking activities to create a business as a nascent entrepreneur. Gartner (1985) identifies four dimensions for factors influencing start-ups and nascent entrepreneurship: the individual, the organization, the environment, and the process.

The following article focuses on individual factors due to two reasons. First, on an individual level, the identified factors help individuals evaluate their potential prospects and difficulties, which influence the founding decision and therefore are especially relevant for predicting the likelihood of founding a business (Rauch and Frese 2000). Second, on a macro-economic level better-designed policy measures contribute to digital start-ups' virtuous cycle (Van Gelderen et al. 2006). Examples for factors along these dimensions concern socio-demographic characteristics, such as age, gender, or human capital, and psychological differences of individuals, such as the perception of risk (Davidsson 2006).

To design effective interventions to increase digital entrepreneurship, we must first identify the relevant factors from the literature and hypothesize their relevance for digital start-ups. We aim to answer the following research questions (RQ) with our research:

- RQ1: Which are the factors influencing individuals in founding a start-up detailed in the literature?

- RQ2: Which are the factors influencing individuals leading to digital entrepreneurship?

- RQ3: Which factors influencing individuals the government should alter to promote digital entrepreneurship?

The following paper structures as follows: Chapter 2 provides the theoretical background. Chapter 3 details the methodological approach. The findings are presented in chapter 4 and discussed in chapter 5 , including limitations and questions for further research.

\section{BACKGROUND}

There are different definitions in the academic and in practitioners' literature. Blank (2003), who is most cited by literature and practitioners, defines a start-up as a temporary organisation created to identify a repeatable and scalable business model. We refer to Skala (2019) for a more detailed review of definitions. In the practitioners' literature, there are very different definitions such as the one used by the European Startup Monitor, which we refer to for the purpose of this research: "1. Start-ups are younger than 10 years 2. Start-ups feature (highly) innovative technologies and/or business models 3. Start-ups have (strive for) significant employee and/or sales growth." (Kollmann et al. 2016, p. 15)

Several previous studies focus on different aspects of digital start-ups or entrepreneurship. For example on concept changes like an innovation of their business model (Ghezzi and Cavallo 2020), success factors like the effects of technology and consumer orientation (Guo et al. 2020), specific contexts like e-learning (Heryandi et al. 2019), or the mindset in the context of digital entrepreneurship (Zaheer et al. 2019). Like Dessyana and Riyanti (2017), some of these have already looked at factors of the entrepreneurs themselves, like entrepreneurial self-efficacy. Still, so far, no study has attempted to identify all relevant factors that influence nascent entrepreneurs.

The most established framework for categorizing factors influencing start-ups by Gartner (1985) identifies four dimensions. He distinguishes founders' characteristics, characteristics of the start-up, of the surrounding environment and of the process by which the start-up is set up (Gartner 1985). For the purpose of this research, we outline therefore the individual factors influencing (digital) nascent entrepreneurs. Individual factors are especially interesting as they are a prerequisite for entrepreneurship.

Since 1985 researchers have examined several factors in detail, including those relevant for nascent entrepreneurs. Van Gelderen et al. (2006) examined success and risk factors. They discussed several individual factors: demographics, gender, age, human capital (work experience), management experience, firm founding, and education. Davidsson (2006) studied personal factors for nascent entrepreneurs, including demographics, resources in terms of human, social and financial capital, and individual psychological characteristics such as personality traits, cognitive characteristics, and motivational patterns. To examine the relevant factors for nascent entrepreneurs of digital start-ups, the following chapter presents the method to generate an overview of these factors and propositions regarding their effect on digital start-ups. 


\section{METHOD}

Following Linnenluecke et al. (2020), we first defined a clear goal for our literature review by focusing on one of the four dimensions by Gartner (1985), namely the individual in the pre-start-up phase. Hence, we only looked after and included research on nascent entrepreneurs only. We decided not to focus on specific outlets to ensure representative coverage as defined by (vom Brocke et al. 2015). We used Google Scholar as a citation indexing service and employed a keyword-based literature search. We used the following keywords in our search: nascent entrepreneur, nascent entrepreneurship, personal traits of founders, firm gestation, venture formation. We reviewed these publications manually for relevance and employed an iterative approach to identify further relevant publications. The references of the publications deemed pertinent to our topic were also a starting point for a systematic backward search. This literature aims to describe, explain, and summarize existing knowledge of individual factors for nascent entrepreneurs (Schryen et al. 2020). We also aim to include theory-building efforts in developing first propositions based on the practitioner's reports and secondary data regarding the relevance of these factors for entrepreneurs' intent on founding digital start-ups. We took the literature factors and searched for supporting evidence in government publications and practitioners' reports to achieve this.

\section{FINDINGS}

\subsection{Individual Factors of Nascent Entrepreneurs}

The literature identifies three dimensions to sort individual factors influencing nascent entrepreneurship: demographics, human capital, and psychological differences of individuals (Gartner 1985; Van Gelderen et al. 2006). The categories and factors within the different dimensions are further elaborated in Table 1. For demographics we outline gender, age, and ethnicity. Human capital considers especially the categories education, experience, skills, role models, and financial capital. Finally, within the psychological differences of the individuals we look at personality and cognitive characteristics as well as the motivational patterns.

Table 1. Effects of different factors on nascent entrepreneurship

\begin{tabular}{|l|l|}
\hline Category (Factor) & Findings (Effects of the factors on nascent entrepreneurships) \\
\hline Demographics & \multicolumn{2}{|l|}{$\begin{array}{l}\text { Gender (Women, } \\
\text { men) }\end{array}$} & $\begin{array}{l}\text { Women are underrepresented as nascent entrepreneurs (e.g. Arenius and Minniti 2005; } \\
\text { Davidsson 2006; Davidsson and Honig 2003; Delmar and Davidsson 2000; Reynolds 1997; } \\
\text { Verheul } \text { et al. 2006 2004b) A lower female participation rate in the workforce serves to explain } \\
\text { the finding (Verheul } \text { et al. 2006). Furthermore, previous research offers different explanations. } \\
\text { On the one hand, Davidsson (2006) concludes that fundamental institutional factors, such as } \\
\text { education and work experiences, result in the differences between male and female nascent } \\
\text { entrepreneurs rather than "innate" differences by sex. Other research does not confirm a } \\
\text { different relative fear of failure (Arenius and Minniti 2005; Wagner 2007) On the other hand, } \\
\text { Minniti and Nardone (2007) show that perceptual variables explain gender differences. } \\
\text { Women have a lower preference for entrepreneurship (Verheul et al. 2011), are less } \\
\text { competitively inclined, and less willing to take risks (Bönte and Piegeler 2013). Women also } \\
\text { have a lower risk tolerance and are less likely to have an internal locus of control (Verheul et } \\
\text { al. 2011). }\end{array}$ \\
\hline $\begin{array}{l}\text { Age (Young people, } \\
\text { especially aged } \\
\text { between 25-34 } \\
\text { years) }\end{array}$ & $\begin{array}{l}\text { Younger people are more likely to become nascent entrepreneurs. Research shows a negative } \\
\text { effect (increasing age reduces the probability to become a nascent entrepreneur) or curvilinear } \\
\text { effect with a peak in the 25-34 years age cohort (Blanchflower 2004; Delmar and Davidsson } \\
\text { 2000; Hopp and Sonderegger 2015; Lévesque and Minniti 2006; Reynolds 1997). }\end{array}$ \\
\hline $\begin{array}{l}\text { Ethnicity } \\
\text { Ethnicity, } \\
\text { minorities, } \\
\text { immigrants) }\end{array}$ & $\begin{array}{l}\text { Previous studies found that some groups (such as immigrants) are over (Delmar and Davidsson } \\
\text { 2000), whereas other groups (of immigrants) are underrepresented. The factors distinguish for } \\
\text { the different groups, such as whites, blacks, and Hispanics in the US (Liu 2012). Possible } \\
\text { research avenues are discrimination in the workforce market, entrepreneurial cultural heritage, } \\
\text { and self-selection of individuals who start in a new country (Davidsson 2006). }\end{array}$ \\
\hline
\end{tabular}




\begin{tabular}{|c|c|}
\hline Category (Factor) & ndings (Effects of the factors on nascent entrepreneurships) \\
\hline \multicolumn{2}{|l|}{ Human Capital } \\
\hline $\begin{array}{l}\text { Education (low to } \\
\text { high Education } \\
\text { level) }\end{array}$ & $\begin{array}{l}\text { A higher level of education increases nascent entrepreneurship. The shape of the relationship } \\
\text { depends on the educational level. Swedish research (Davidsson 2006; Davidsson and Honig } \\
\text { 2003; Delmar and Davidsson 2000) shows positive effects of education levels, including } \\
\text { higher ones, whereas US and international-comparative analyses indicate that above medium } \\
\text { levels of education do not increase the probability to become a nascent entrepreneur (Arenius } \\
\text { and Clercq 2005; Davidsson 2006; Kim } \text { et al. 2003; Reynolds 1997; Wagner 2004a). }\end{array}$ \\
\hline $\begin{array}{l}\text { Experience (Start- } \\
\text { up experience, } \\
\text { Self employment } \\
\text { Management or } \\
\text { work/industry } \\
\text { experience }\end{array}$ & $\begin{array}{l}\text { Previous start-up experience or self-employment has positive effects on nascent } \\
\text { entrepreneurship (Davidsson 2006; Davidsson and Honig 2003; Delmar and Davidsson 2000; } \\
\text { Kim et al. 2003). Some studies found that management or work experience has a weak or } \\
\text { uncertain effect (Davidsson 2006; Davidsson and Honig 2003; Delmar and Davidsson 2000; } \\
\text { Kim et al. 2003). Other research found a positive effect for years of work experience and call } \\
\text { for a more detailed assessment of the different types of work experience (Hopp and } \\
\text { Sonderegger 2015; Zanakis et al. 2012). For example, work experience in young and small } \\
\text { firms increases the probability to found a business (Wagner 2004a). }\end{array}$ \\
\hline $\begin{array}{l}\text { Skills (Task- } \\
\text { relatedness; } \\
\text { Balanced skills; } \\
\text { Self-confidence in } \\
\text { having the relevant } \\
\text { skills, self-efficacy } \\
\text { and persistence; } \\
\text { Opportunity } \\
\text { confidence) }\end{array}$ & $\begin{array}{l}\text { Knowledge and skills (outcomes of human capital investments) are more critical for young } \\
\text { firms' success than education and experiences (human capital investments), especially when } \\
\text { they are more task-related (Unger } \text { et al. 2011). People with balanced skills engage more likely } \\
\text { as nascent entrepreneurs. The balanced skills originate from entrepreneurial talent (endowment } \\
\text { hypothesis) as well as interests in an entrepreneurial career and entrepreneurial and managerial } \\
\text { experiences (investment hypothesis) (Stuetzer et al. 2013). There is a strong effect of self- } \\
\text { reported confidence in own skills and self-efficacy on persistence and the probability to } \\
\text { become a nascent entrepreneur (Arenius and Minniti 2005; Chen } \text { et al. 1998; Hechavarria et al. } \\
\text { 2012; Hopp and Sonderegger 2015; Wagner 2004b; Zanakis } \text { et al. 2012). A person considering } \\
\text { an opportunity as feasible and having the confidence to own the relevant skills (opportunity } \\
\text { confidence) is more likely to become a nascent entrepreneur (Dimov 2010). }\end{array}$ \\
\hline $\begin{array}{l}\text { dels }(\text { Self- } \\
\text { d parents, } \\
\text { or }\end{array}$ & $\begin{array}{l}\text { Self-employed parents, friends, or relatives acting as role models as well as being encouraging } \\
\text { indicate positive effects on nascent entrepreneurship (Arenius and Minniti 2005; Bosma et al. } \\
\text { 2011; Davidsson and Honig 2003; Delmar and Davidsson 2000; Delmar and Gunnarsson 2000; } \\
\text { Kim et al. 2003; Verheul et al. 2011; Wagner 2004b). }\end{array}$ \\
\hline $\begin{array}{l}\text { Financial capital } \\
\text { (Indicators of } \\
\text { income and } \\
\text { household net } \\
\text { worth) }\end{array}$ & $\begin{array}{l}\text { The findings are ambiguous, and the relationship between financial capital is more } \\
\text { complicated than a simple, linear, positive one. Research assumes that opportunity-based and } \\
\text { necessity-based entrepreneurship confound. Unemployment increases the probability of } \\
\text { becoming an entrepreneur; however, the financial situation is not the best predictor (Arenius } \\
\text { and Minniti 2005; Davidsson 2006; Reynolds 1997; Wagner 2004b). }\end{array}$ \\
\hline \multicolumn{2}{|c|}{ Psychological differences of the individuals } \\
\hline $\begin{array}{l}\text { Personality } \\
\text { characteristics } \\
\text { (Locus of control, } \\
\text { need for } \\
\text { achievement, } \\
\text { innovativeness, } \\
\text { stress tolerance, } \\
\text { need for autonomy } \\
\text { Risk taking) }\end{array}$ & $\begin{array}{l}\text { An internal locus of control increases the decision to become an entrepreneur (Verheul et al. } \\
\text { 2011). Furthermore, Rauch and Frese (2007) found that the need for achievement, innovative- } \\
\text { ness, stress tolerance and need for autonomy correlate with entrepreneurial behavior of } \\
\text { business creation. Nascent entrepreneurs do not have a higher tolerance for risk. However, they } \\
\text { perceive existing risks as smaller (Baron 2004). Caliendo et al. (2009) even found in an } \\
\text { experiment that the conventional wisdom that nascent entrepreneurs are less risk-averse, at } \\
\text { least if they were previously employed. This finding is contrary to previous research. In the } \\
\text { end, a lower risk aversion, or at least a risk perception, increases the probability of an } \\
\text { individual becoming a nascent entrepreneur (Simon et al. 2000). }\end{array}$ \\
\hline $\begin{array}{l}\text { Cognitive charac- } \\
\text { teristics (Overopti- } \\
\text { mism; Illusion of } \\
\text { control; Prospect } \\
\text { theory; Fear of } \\
\text { failure; Economic } \\
\text { outlook; Perception } \\
\text { of opportunities) }\end{array}$ & $\begin{array}{l}\text { Entrepreneurs are overly optimistic, shown by planning fallacy and base rate neglect. Instead } \\
\text { of focusing on comparable cases and base rates, nascent entrepreneurs focus on the problems' } \\
\text { specifics, resulting in over-optimism of plans and projections (Cassar 2010). The illusion of } \\
\text { control and the belief in small numbers result in lower risk perception, increasing the } \\
\text { probability to engage in nascent entrepreneurship (Simon et al. 2000). Another supporting } \\
\text { factor is the overweight of small probabilities (Baron 2004). Lower fear of failure, a more } \\
\text { positive economic outlook for family, and a higher opportunity perception are positively } \\
\text { related to nascent entrepreneurship (Arenius and Minniti 2005; Davidsson 2006; Wagner } \\
\text { 2004b). }\end{array}$ \\
\hline
\end{tabular}




\begin{tabular}{|l|l|}
\hline Category (Factor) & Findings (Effects of the factors on nascent entrepreneurships) \\
\hline $\begin{array}{l}\text { Motivational } \\
\text { patterns (Push and } \\
\text { pull factors; Rebel } \\
\text { theory; Expectancy } \\
\text { theory) }\end{array}$ & $\begin{array}{l}\text { Different push factors (for example, lack of alternatives) or pull factors (for example, seek for } \\
\text { challenge or autonomy) motivate individuals to become an entrepreneur (Van Gelderen } \text { et al. } \\
\text { 2006). In a group comparison between nascent entrepreneurs and non-nascent entrepreneurs, } \\
\text { Carter et al. found no effects for innovative and financial motivation as well as self-realization } \\
\text { or independence. Nascent entrepreneurs care less about external recognition and follow fewer } \\
\text { role expectations. The findings support the "rebel" theory of entrepreneurship (Carter } \text { et al. } \\
\text { 2003; Davidsson 2006) (Carter et al. 2003; Davidsson 2006). Renko et al. (2012) found that } \\
\text { expectancy theory and, therefore all types of valence (attractive reward or outcome), } \\
\text { instrumentality (greater reward if they meet performance expectations), and expectancy (the } \\
\text { probability that efforts result in desired goals) are related to a conscious effort. }\end{array}$ \\
\hline
\end{tabular}

In the following chapter, we examine the relevance of these factors for digital entrepreneurs and develop the first hypotheses regarding their effect.

\subsection{Hypotheses Regarding the Relevance for Digital Start-Ups}

To design interventions to increase the number of nascent digital entrepreneurs and digital start-ups, we developed eight hypotheses addressing the categories mentioned above. The developed interventions serve as starting points. Future research is required to design more interventions, for example, regarding the category gender by evaluating STEM education or risk tolerance of women.

Research on digital entrepreneurship is growing and covers various facets such as digital mindset, gender differences, and human capital. A digital mindset promotes successful digital start-ups. A deep understanding of the open, faster scalable, generative nature of digital technologies combined with an entrepreneurial attitude fosters digital entrepreneurship (Zaheer et al. 2019). Other research found that the internet is not a meritocratic space for entrepreneurship, but instead, it reproduces specific offline effects such as social positionality and connected resource constraints (Dy et al. 2017). Literature also evaluates founders' human capital in technology firms, revealing that complementary skills such as technical education and commercial experience (Ganotakis 2012). Our hypotheses build on these findings and propose further research.

Starting with the first dimension, demographics, according to the practitioner's literature, women are less likely founding start-ups in the sector of information and computer technology than men (Hirschfeld et al. 2020). We assume that, among other factors, especially the lack of female role models, reinforces this discrepancy. Since research has shown a strong influence of role models on nascent entrepreneurs (Arenius and Minniti 2005; Bosma et al. 2011; Davidsson and Honig 2003; Delmar and Davidsson 2000; Delmar and Gunnarsson 2000; Kim et al. 2003; Verheul et al. 2011; Wagner 2004b), we propose to test the following hypothesis: Hypothesis 1 (gender): Female digital entrepreneurs acting actively as role models promote female digital entrepreneurship.

As previous research has shown, the affinity towards digital technologies, such as the acceptance of internet technologies, decreases with age (Niehaves and Plattfaut 2014). We assume that a lack of acceptance regarding digital technologies also negatively influences the intention to become a nascent digital entrepreneur. Therefore, the second hypothesis is: Hypothesis 2 (age): Increasing technology acceptance for older people promote digital entrepreneurship among them.

We assume that there are no peculiarities regarding nascent entrepreneurship in digital start-ups for the category of ethnicity. Regarding the second dimension, human capital, the financial aspect is not as crucial for digital start-ups as for start-ups in many other sectors. As marginal costs of software are low and especially cloud technologies allow low-cost testing of ideas, most digital start-ups should not require enormous upfront costs as in other industries, such as in the pharmaceutical sector (Zaheer et al. 2019). Therefore, we focused on hypotheses 3 - 6 on increasing nascent entrepreneurship by higher digital education levels, more IT (start-up) experiences, IT-related skills, and successful digital entrepreneurs acting as role models.

Hypothesis 3 (education): Education in STEM and related fields increases digital entrepreneurship. Hypothesis 4 (experience): Prior work in IT start-ups, IT departments, or other IT related contexts increase digital entrepreneurship. 
Hypothesis 5 (skills): Coding skills or other relevant digital skills increase digital entrepreneurship. Hypothesis 6 (role models): More positive successful national digital entrepreneurs could function as role models and increase digital entrepreneurship.

In the third dimension, psychological differences of the individuals, hypothesis 7 and 8 focus on the cognitive characteristics and motivational patterns since personality characteristics are supposed to be very stable. Regarding cognitive characteristics, we derive the following two hypotheses: Hypothesis 7 (cognitive characteristics): Following prospect theory, framing risks of digital start-ups differently or putting them into different contexts increases digital entrepreneurship.

Hypothesis 8 (cognitive characteristics): Improving the skills to perceive digital opportunities and transfer technological solutions from other contexts increases digital entrepreneurship.

\section{DISCUSSION}

We identified several factors influencing individuals in founding or not founding a start-up detailed in the literature, along our two research questions. We then developed hypotheses regarding the relevance of the factors in influencing individuals regarding digital entrepreneurship.

Our findings offer several theoretical and practical contributions. The three significant theoretical contributions are: Firstly, our results represent an overview of individual factors influencing an individual's probability to become a (nascent) entrepreneur for start-ups in general. This overview represents the first step to develop a more comprehensive model describing individual factors which influence people to become engaged in digital start-up efforts. Secondly, we derived hypotheses regarding the relevance of these factors for digital start-ups. Thirdly, we propose the first experimental approaches to test for the effectiveness of countermeasures. The findings also have two practical contributions on different societal levels: On the individual level, this overview of individual factors can support an individual in rationalizing and structuring the decision to become a digital entrepreneur. On a broader level, we identify the factors that ultimately lead to an individual's decision to engage in digital entrepreneurship and, therefore, levers of governments to increase digital entrepreneurship and economic growth in the long run by shaping these factors.

This research comes with some limitations. The pre-funding "process" was considered as one step albeit it can be detailed further. We focused on factors relevant to increase digital entrepreneurship. The factors relevant in that phase might have a negative impact on the start-ups development in it's later life cycle. Finally factors might overlap e.g., gender and role modeling in the case of a lack of female role models. Here further research regarding interdependencies of factors is necessary.

Future research should focus on a qualitative study in interviews, focus groups, and observations to develop a holistic model, including the direct and indirect effects of the different factors. Researchers should then test this developed model in quantitative studies (e.g., experiments). The model should focus on individual factors since they seem to drive nascent entrepreneurs (qualitative study). It should also include environmental, organizational, and process factors to achieve a comprehensive model (Rotefoss and Kolvereid 2005). These efforts should be to test effective means to influence the number of nascent entrepreneurs positively. In this regard, it can also be helpful to assess the effect of measures separately as an intermediary step.

\section{REFERENCES}

Ahlstrom, D. 2010. Innovation and Growth: How Business Contributes to Society. In Academy of Management Perspectives. Vol. 24 No. 3, pp. 11-24.

Arenius, P. and Clercq, D. 2005. A Network-based Approach on Opportunity Recognition. In Small Business Economics. Vol. 24 No. 3, pp. 249-265.

Arenius, P. and Minniti, M. (2005), "Perceptual Variables and Nascent Entrepreneurship", Small Business Economics. Vol. 24 No. 3, pp. 233-247.

Baron, R.A. 2004. The Cognitive Perspective: A Valuable Tool for Answering Entrepreneurship's Basic 'why' Questions. In Journal of Business Venturing. Vol. 19 No. 2, pp. 221-239.

Blanchflower, D. 2004. Self-Employment: More May not Be Better. In NBER Working Paper Series. pp. 1-59.

Blank, S. 2003. The Four Steps to the Epiphany: Successful Strategies for Products That Win. John Wiley \& Sons. 
Bönte, W. and Piegeler, M. 2013. Gender Gap in Latent and Nascent Entrepreneurship: Driven by Competitiveness. In Small Business Economics. Vol. 41 No. 4, pp. 961-987.

Bosma, N. et al 2011. Entrepreneurship and Role Models. In Journal of Economic Psychology. Vol. 33, No. 2, pp. 410-424

Bosma, N. et al 2020. Global Entrepreneurship Monitor 2019/2020. Global Report.

vom Brocke, J. et al 2015. Standing on the Shoulders of Giants: Challenges and Recommendations of Literature Search in Information Systems Research. In Communications of the Association for Information Systems. Vol. 37, pp. 205-224.

Caliendo, M. et al 2009. Risk Attitudes of Nascent Entrepreneurs-New Evidence from an Experimentally Validated Survey. In Small Business Economics. Vol. 32 No. 2, pp. 153-167.

Carter, N.M. et al 2003. The Career Reasons of Nascent Entrepreneurs. In Journal of Business Venturing. Vol. 18 No. 1 , pp. 13-39.

Cassar, G. 2010. Are Individuals Entering Self-Employment Overly Optimistic? An Empirical Test of Plans and Projections on Nascent Entrepreneur Expectations. In Strategic Management Journal. Vol. 31 No. 8, pp. 822-840.

Chen, C.C. et al 1998. Does Entrepreneurial Self-efficacy Distinguish Entrepreneurs from Managers? In Journal of Business Venturing. Vol. 13 No. 4, pp. 295-316.

Davidsson, P. 2006. Nascent entrepreneurship: empirical studies and developments. In Foundations and Trends in Entrepreneurship. Now publishers inc.Vol. 2 No. 1, pp. 1-76.

Davidsson, P. and Honig, B. 2003. The Role of Social and Human Capital among Nascent Entrepreneurs. In Journal of Business Venturing. Vol. 18 No. 3, pp. 301-331.

Delmar, F. and Davidsson, P. 2000. Where Do They Come From? Prevalence and Characteristics of Nascent Entrepreneurs. In Entrepreneurship and Regional Development. Vol. 12 No. 1, pp. 1-23.

Delmar, F. and Gunnarsson, J. 2000. How Do Self-employed Parents of Nascent Entrepreneurs Contribute?. In Frontiers of Entrepreneurship Research. pp. 150-162.

Dessyana, A. and Riyanti, B.P.D. 2017. The Influence of Innovation and Entrepreneurial Self-Efficacy to Digital Startup Success. In International Research Journal of Business Studies. Vol. 10 No. 1, pp. 57-68.

Dimov, D. 2010. Nascent Entrepreneurs and Venture Emergence: Opportunity Confidence, Human Capital, and Early Planning. In Journal of Management Studies. Vol. 47 No. 6, pp. 1123-1153.

Dy, A.M. et al 2017. A Web of Opportunity or the Same Old Story? Women Digital Entrepreneurs and Intersectionality Theory. In Human Relations. Vol. 70 No. 3, pp. 286-311.

Ganotakis, P. 2012. Founders' human capital and the performance of UK new technology based firms. In Small Business Economics. Vol. 39 No. 2, pp. 495-515.

Gartner, W.B. 1985. A Conceptual Framework for Describing the Phenomenon of New Venture Creation. In the Academy of Management Review. Vol. 10 No. 4, pp. 696-706.

Van Gelderen, M. er al 2006. Success and Risk Factors in the Pre-Startup Phase. In Small Business Economics. Vol. 26 No. 4, pp. 319-335.

Ghezzi, A. and Cavallo, A. 2020. Agile Business Model Innovation in Digital Entrepreneurship: Lean Startup Approaches. In Journal of Business Research. Vol. 110, pp. 519-537.

Global Entrepreneurship Research Association 2020. Diagnosing COVID-19 Impacts on Entrepreneurship Exploring Policy Remedies for Recovery. Available at: https://www.gemconsortium.org/reports/covid-impact-report.

Guo, H. et al 2020. Technology Push or Market Pull? Strategic Orientation in Business Model Design and Digital Start-up Performance. In Journal of Product Innovation Management, Vol. 37 No. 4, pp. 352-372.

Hechavarria, D.M. et al 2012. The Nascent Entrepreneurship Hub: Goals, Entrepreneurial Self-efficacy and Start-up Outcomes. In Small Business Economics. Vol. 39 No. 3, pp. 685-701.

Heryandi, A. et al 2019. Digital Startup Implementation in E-learning. In Journal of Physics: Conference Series, Vol. 1402 No. 6.

Hirschfeld, A. et al 2020. Female Founders Monitor 2020. Available at: www.wagasowa.de.

Hopp, C. and Sonderegger, R. 2015. Understanding the Dynamics of Nascent Entrepreneurship-Prestart-Up Experience, Intentions, and Entrepreneurial Success. In Journal of Small Business Management. Vol. 53 No. 4, pp. 1076-1096.

Kim, P.H. et al 2003. If I Were Rich? The Impact of Financial and Human Capital on Becoming a Nascent Entrepreneur. In the Annual Meeting of the American Sociological Association.

Kollmann, T. et al 2016. European Startup Monitor 2016.

Kuckertz, A. et al. 2020. Startups in times of crisis - A rapid response to the COVID-19 pandemic. In Journal of Business Venturing Insights. Vol. 13.

Lévesque, M. and Minniti, M. 2006. The Effect of Aging on Entrepreneurial Behavior. In Journal of Business Venturing. Vol. 21 No. 2, pp. 177-194.

Linnenluecke, M.K. et al 2020. Conducting Systematic Literature Reviews and Bibliometric Analyses. In Australian Journal of Management. Vol. 45 No. 2, pp. 175-194. 
Liu, C.Y. 2012. The Causes and Dynamics of Minority Entrepreneurial Entry. In Journal of Developmental Entrepreneurship. Vol. 17 No. 1, pp. 1-23.

Metzger, G. 2020. KfW-Gründungsmonitor 2020 Gründungstätigkeit in Deutschland 2019: Erster Anstieg Seit 5 Jahren 2020 Im Schatten Der Corona- Pandemie. In KfW Research.

Minniti, M. and Nardone, C. 2007. Being in Someone Else's Shoes: The Role of Gender in Nascent Entrepreneurship. In Small Business Economics. Vol. 28 No. 2, pp. 223-238.

Niehaves, B. and Plattfaut, R. 2014. Internet Adoption by the Elderly: Employing IS Technology Acceptance Theories for Understanding the Age-Related Digital Divide. In European Journal of Information Systems. Vol. 23 No. 6 , pp. 708-726.

Overall, J. and Wise, S. 2015. An S-Curve Model of the Start-Up Life Cycle Through the Lens of Customer Development. In the Journal of Private Equity. Vol. 18 No. 2, pp. 23-34.

Rauch, A. and Frese, M. 2000. Psychological Approaches to Entrepreneurial Success. A General Model and an Overview of Findings. Cooper, C.L. and Robertson, I.T. (Eds.). In International Review of Industrial and Organizational Psychology, pp. 101-142.

Rauch, A. and Frese, M. 2007. Let's Put the Person Back into Entrepreneurship Research: A Meta-Analysis on the Relationship Between Business Owners' Personality Traits, Business Creation, and Success. In European Journal of Work and Organizational Psychology. Vol. 16 No. 4, pp. 353-385.

Reisdorfer-Leite, B. et al 2020. Startup Definition Proposal Using Product Lifecycle Management. In IFIP International Conference on Product Lifecycle Management. pp. 426-435.

Renko, M. et al. 2012. Expectancy Theory and Nascent Entrepreneurship. In Small Business Economics. Vol. 39 No. 3 , pp. 667-684.

Reynolds, P.D. 1997. Who Starts New Firm? Preliminary Explanation of Firm-in-Gestation. In Small Business Economics. Vol. 9 No. 5, pp. 449-462.

Rotefoss, B. and Kolvereid, L. 2005. Aspiring, Nascent and Fledging Entrepreneurs: An Investigation of the Business Start-up Process. In Entrepreneurship and Regional Development. Vol. 17 No. 2, pp. 109-127.

Schryen, G. et al 2020. A Knowledge Development Perspective on Literature Reviews: Validation of a New Typology in the IS Field. In Communications of the Association for Information Systems. Vol. 46, pp. 134-186.

Simon, M. et al 2000. Cognitive Biases, Risk perception, and Venture Formation: How Individuals Decide to Start Companies. In Journal of Business Venturing. Vol. 15 No. 2, pp. 113-134.

Skala, A. 2019. Digital Startups in Transition Economies, Springer International Publishing.

Skawińska, E. and Zalewski, R.I. 2020. Success Factors of Startups in the EU - A Comparative Study. In Sustainability, Vol. 12 No. 19.

Soto-Acosta, P. 2020. COVID-19 Pandemic: Shifting digital transformation to a high-speed gear. In Information Systems Management, Taylor \& Francis. Vol. 37 No. 4, pp. 260-266.

Stuetzer, M. et al 2013. Balanced Skills among Nascent Entrepreneurs. In Small Business Economics. Vol. 41 No. 1, pp. 93-114.

Summers, D. 2015. The economic impact of entrepreneurship: setting realistic expectations. In Academy of Entrepreneurship Journal. Vol. 21 No. 2, pp. 99-107.

Unger, J.M. et al 2011. Human Capital and Entrepreneurial Success: A Meta-analytical Review. In Journal of Business Venturing. Elsevier Inc, Vol. 26 No. 3, pp. 341-358.

Verheul, I. et al 2006. Explaining Female and Male Entrepreneurship at the Country Level. In Entrepreneurship and Regional Development. Vol. 18 No. 2, pp. 151-183.

Verheul, I. et al 2011. Explaining Preferences and Actual involvement in Self-employment: Gender and the Entrepreneurial Personality. In Journal of Economic Psychology. Elsevier B.V., Vol. 33 No. 2, pp. 325-341.

Wagner, J. 2004a. Are Young and Small Firms Hothouses for Nascent Entrepreneurs? Evidence from German Micro Data. In IZA Discussion Papers. Vol. No. 989, pp. 1-17.

Wagner, J. 2004b. Nascent Entrepreneurs, Discussion Paper. Available at:https://doi.org/10.1007/978-0-387-32313-8_2.

Wagner, J. 2007.What a Difference a Y makes-Female and Male Nascent Entrepreneurs in Germany. In Small Business Economics. Vol. 28 No. 1, pp. 1-21.

Zaheer, H. et al 2019. Straight From the Horse's Mouth: Founders' Perspectives on Achieving 'traction' in Digital Start-ups. In Computers in Human Behavior. Elsevier Ltd, Vol. 95, pp. 262-274.

Zanakis, S.H. et al 2012, Nascent Entrepreneurs and the Transition to Entrepreneurship: Why Do People Start New Businesses? In Journal of Developmental Entrepreneurship, Vol. 17 No. 1, pp. 1-25. 